\title{
Proposal of High Gain, Reduced Stress with Low-Duty-Cycle Two-Input Boost Converter for Renewable Energy Systems
}

\author{
L. Chitra ${ }^{1}$, M. Karpagam ${ }^{2}$, K. Saranyadevi ${ }^{1}$ \\ ${ }^{1}$ Department of Electrical and Electronics Engineering, Dr Mahalingam College of Engineering and Technology, \\ Pollachi, Tamil Nadu, India \\ ${ }^{2}$ Department of Electrical and Electronics Engineering, Hindusthan College of Engineering and Technology, \\ Coimbatore, Tamil Nadu, India \\ Email: "santum17@rediffmail.com
}

Received 9 March 2016; accepted 26 April 2016; published 29 April 2016

Copyright (C) 2016 by authors and Scientific Research Publishing Inc.

This work is licensed under the Creative Commons Attribution International License (CC BY). http://creativecommons.org/licenses/by/4.0/

(c) (i) Open Access

\begin{abstract}
A two-input boost converter with voltage multiplier cell is proposed in this paper. Then a family of two-input converters with and without voltage multiplier cell are derived and their results are compared to achieve high voltage gain, low duty cycle, and reduced voltage stress. From the analysis of different topologies, a modified two-input converter with two-stage voltage multiplier cell has good operating characteristics. The switch voltage stress and duty cycle of the modified converter is significantly very less than that of the other converter topologies. The modified DC-DC converter with $50 \%$ duty cycle achieves a voltage gain of 10 and the results are verified by using MATLAB/Simulink software.
\end{abstract}

\section{Keywords}

Voltage Multiplier Cell (VMC), DC-DC Converter; Boost Converter, Simulink, Voltage Gain, Voltage Stress, Duty Cycle

\section{Introduction}

Boost converter with high gain finds applications in various renewable energy sources such as solar energy systems, fuel cell systems and also in electric vehicles. Mostly two types of DC-DC converters are present and they are: transformer less (isolated DC-DC converter) and with transformer (non-isolated DC-DC converter) [2].

\footnotetext{
*Corresponding author.
} 
However the transformer less topology attains good performance in terms of efficiency and other parameters compared to transformer topology [1].

The size and efficiency of the power transformer is a major constraint of the isolated DC-DC converters. Some non-isolated DC-DC converters such as boost can provide increased voltage gain but the voltage, current stress and duty cycle are high [1]-[3]. During the operation of the converter at high current and voltage levels, the diode reverse recovery current reduces the efficiency of the converter. Some of the non-isolated topologies can work with high voltage gain as the quadratic boost and with auxiliary circuits can obtain soft-switching, but the switch voltage stress and the losses are high. The inclusion of voltage multiplier in low frequency rectifiers is a classical solution to increase the DC output voltage. This technique is also used in high-frequency isolated DC-DC converters, mainly for high output voltage $(\mathrm{kV})$ applications as in Travelling Wave Tube Amplifiers (TWTA), reducing the problems presented by high-frequency and high-voltage power transformer [4]. The voltage multiplier method can be combined with non-isolated DC-DC converters to attain new operation characteristics. The main advantages obtained are increased voltage gain, reduced switch voltage stress, soft switching and reduced reverse recovery current problems. The VMC works as a regenerative clamping circuit and it has low EMI and reduced size. These options permit work with high voltage gain, less losses and compact circuit for applications wherever the isolation isn't essential [5]-[8]. The boost and buck-boost converters are able to achieve high voltage gain with a large duty cycle. However, the voltage gain is limited by the size of power devices, inductance and capacitance parameters [9]. Also, the switch voltage stress is high, which makes the lower-voltage and high performance devices inappropriate. Moreover, the large duty cycle induces high-current ripples, which in turn increase the conduction losses and induce reverse-recovery problem which in turn reduce the efficiency and limit the power level [10]. Cascade boost converters or cascade three-level boost converters are attractive solutions [11]. But they are very complex because they need two sets of power devices, magnetic cores and control circuits. And the stability of the cascade structure is another concern [12]. A severe rectifier reverse- recovery problem occurs in the second stage because the diode used in the second stage needs to sustain high voltage level. So the efficiency is low and the EMI noise is serious.

The proposed modified two-input converter has high step-up voltage gain with reduced component count, reduced voltage stress across the switches and diodes which in turn reduce both switching and conduction losses. The voltage and current stress of the devices are also less because of low duty cycle.

This paper is organized as follows. The generation of the new converter family is presented in Section 2, and the principle of operation is also given. An extension of the new topology to other topologies is also presented in Section 2. The simulation results are presented in Section 3. The comparison of different topologies is presented in Section 4 and the conclusion is given in Section 5.

\section{Family of Two-Input DC-DC Converters with and without Voltage Multiplier Cell}

\subsection{Two-Input Boost Converter without Voltage Multiplier Cell}

The two-input boost converter without voltage multiplier cell is shown in Figure 1. The circuit is derived from the conventional boost converter. Two converters are connected in parallel for the two inputs. Two power switches S1, S2 in the converter structure are the main controllable elements that control the power flow of the hybrid system. The circuit topology enables the switches to be independently controlled through four independent duty ratios $\mathrm{d} 1, \mathrm{~d} 2$ respectively. The diodes D1 and D2 conduct in complementary manner with switches S1 and S2. In hybrid power systems applications, the main aim is to achieve an acceptable current ripple in order to fix the output power on desired value. So, the current ripple of the input sources is reduced to make power balance among the input and load.

A. First Operation Mode: In Mode 1, the switch S1 \& S2 are turned ON. So the input voltage vin1 charges the input inductor L1 and input voltage vin2 charges the input inductor L2. Due to this, there is no conduction in diodes D1, D2.So that the load is isolated from the input.

B. Second Operation Mode: In Mode 2 Operation, the switch S1 \& S2 are turned OFF. So the diodes come to conduction and the input inductors current flows through diode D1 \& D2 and capacitance C01 \& C02 to load so the capacitors C01 \& C02 gets charging. When the switches are OFF, current in the diodes is reduced to zero. So the diode D1 \& D2 is blocked. It will minimize diode reverse recovery current also with low di/dt. So that capacitors are discharges the energy to load. 


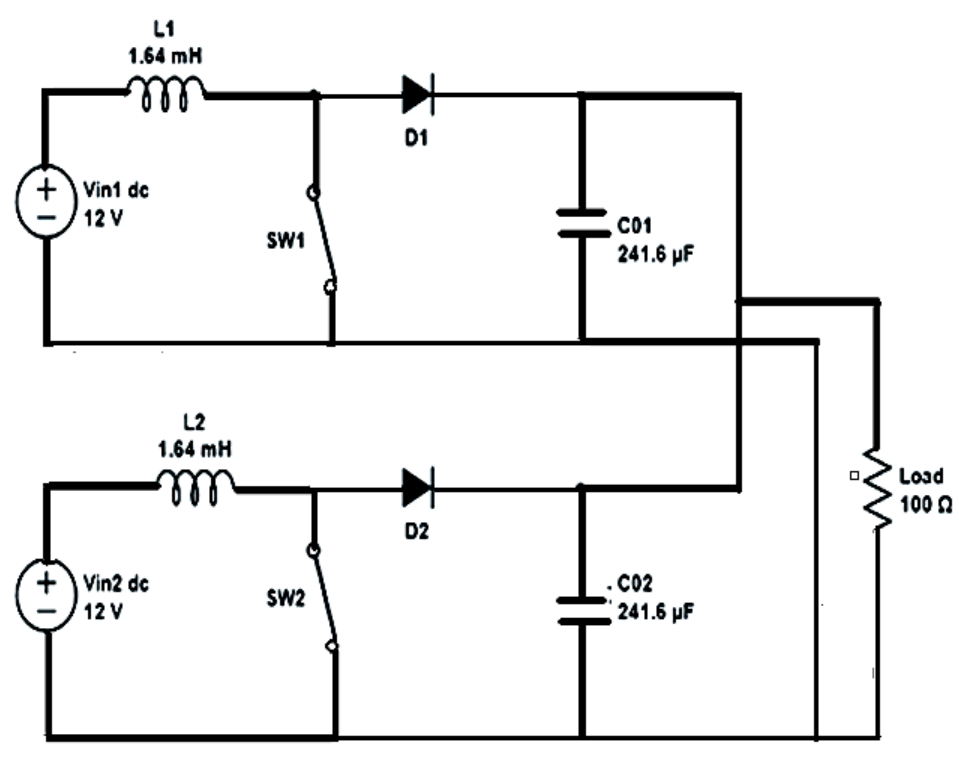

Figure 1. Two-input boost converter without voltage multiplier cell.

\subsection{Proposed Two-Input VMC with Voltage Multiplier Cell}

The two-input boost converter with voltage multiplier cell is shown in Figure 2. The circuit is derived from the conventional Boost converter. Two converters are connected in parallel for the two inputs and voltage multiplier cell is inserted in the output side of each converter.

A. First Operation Mode: When the switches S1 \& S2 are turned OFF, the energy stored in the input inductor Lin1 \& Lin2 will be transferred to the multiplier capacitor CM1 \& CM2 through the diodes DM1 \& DM2 respectively. The resonant inductor current ( $\operatorname{Lr} 1 \& \operatorname{Lr} 2)$ rise linearly from zero to the maximum value of the input inductor currents $\left(\mathrm{I}_{\mathrm{Lin} 1} \& \mathrm{I}_{\mathrm{Lin} 2}\right)$ and the current in the diode DM1 \& DM3 is reduced at same proportion.

B. Second Operation Mode: At the instant (t1), the current in the diode DM1 \& DM3 is zero and this diode is blocked with low di/dt, minimizing the diode reverse recovery current. The resonant inductor current is same as the input inductor current during this stage and the energy stored in the input inductor is transferred to the load through the diodes Do1 \& Do2.

C. Third Operation Mode: At time instant (t2), the switches S1 \& S2 are turned-on with zero current and the current in the resonant inductor Lr1 \& Lr2 and in the output diode D01 \& D02 reduces linearly until zero, at time instant (t3). Thus the reverse recovery current of the output diode is also minimized.

D. Fourth Operation Mode: When output diode is blocked, DM2 \& DM4 conducts and transfers part of the energy stored in the capacitors CM1 to CM2 and CM3 to CM4. When there is a balance of energy between the multiplier capacitors, the diode DM2 \& DM4 are blocked (t4) also with low di/dt. During the switch turn-on the input inductor stores energy as the classical boost.

\subsection{Two-Input Boost Converter with \& without Voltage Multiplier Cell}

The two-input boost converter with and without voltage multiplier cell is shown in Figure 3. The circuit is derived from the conventional Boost converter. Two converters are connected in parallel for the two inputs and voltage multiplier cell is inserted in the output side of one converter.

A. First Operation Mode: In this mode S1 is turned ON and S2 is turned OFF. The input voltage charges the input inductor Lin1 and energy stored in the inductor Lin2 is transferred to CM1 through the diode DM1. The resonant inductor current $\left(\mathrm{I}_{\mathrm{Lr}}\right)$ rises linearly from zero until to reach the value of the input inductor current $\left(\mathrm{I}_{\mathrm{Lin} 1}\right)$ and the current in the diode DM1 is reduced at same the quantity. The resonant inductor current which in turn charges the output capacitor Co through the diode D0.

B. Second Operation Mode: In this mode S1 is turned OFF and S2 is turned OFF. The current in the diode DM1 is zero and this diode is blocked with low di/dt, minimizing the diode reverse recovery current. The resonant inductor current is same as the input inductor current and the energy of the input inductor is transferred to 


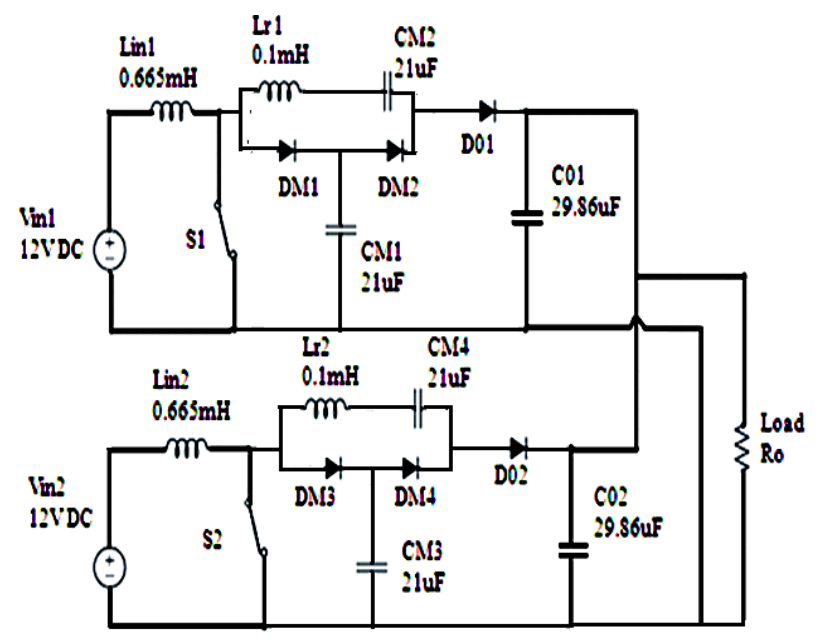

Figure 2. Two-input VMC with VMC.

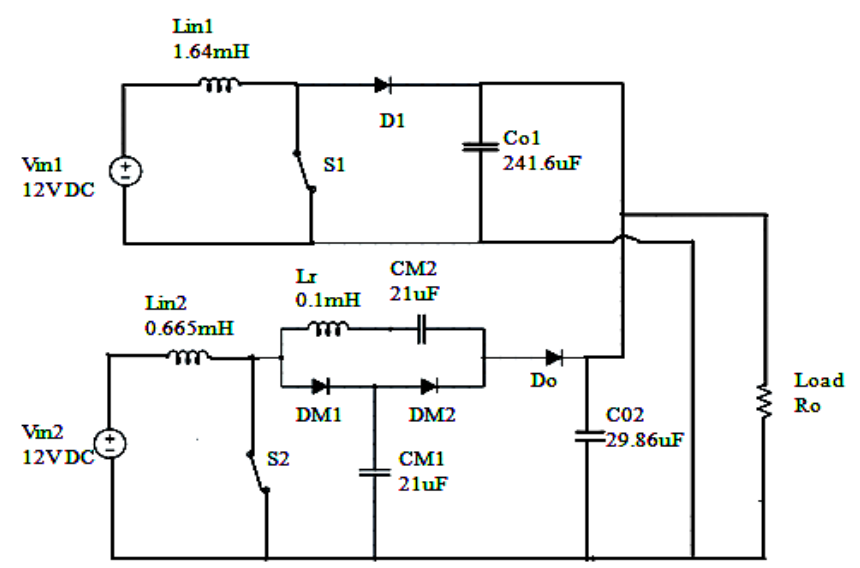

Figure 3. Two-input boost converter with and without VMC.

the load through the diode Do.

C. Third Operation Mode: In this mode switches S1 and S2 are turned ON and the resonant inductor Lr and the output diode Do current reduces linearly to zero. Thus the reverse recovery current of the output diode is also minimized.

D. Fourth Operation Mode: In this mode S1 is turned ON and S2 is turned ON, when output diode is blocked, DM2 conducts transferring part of the energy stored in the capacitor CM1 to the capacitor CM2 in resonant way. When there is a balance of energy between the multiplier capacitors, the diode DM2 is blocked (t4) also with low di/dt. During the switch turn on the input inductor stores some energy as the classical boost.

\subsection{Modified Two-Input Boost Converter with Voltage Multiplier Cell}

The modified two-input boost converter with voltage multiplier cell is shown in Figure 4. The circuit is derived from the conventional Boost converter. Two converters are connected in parallel for the two inputs and a two stage voltage multiplier cell is inserted as common between the output sides of both converters.

A. First Operation Mode 1: In this mode both switches S1 and S2 are ON. Both the inductors are charged from their input sources Vin1 and Vin2. The current in both the inductors rise linearly. The diodes in different VM stages are reverse biased and do not conduct. The VM capacitor voltages remain unchanged and the output diode Do is reverse biased. Thus the load is supplied by the output capacitor Co.

B. Second Operation Mode 2: In this mode switch S1 is OFF and S2 is ON. All the odd numbered diodes are forward biased and the inductor current $\mathrm{I}_{\mathrm{Lin} 1}$ flows through the voltage multiplier capacitors charging the capa- 


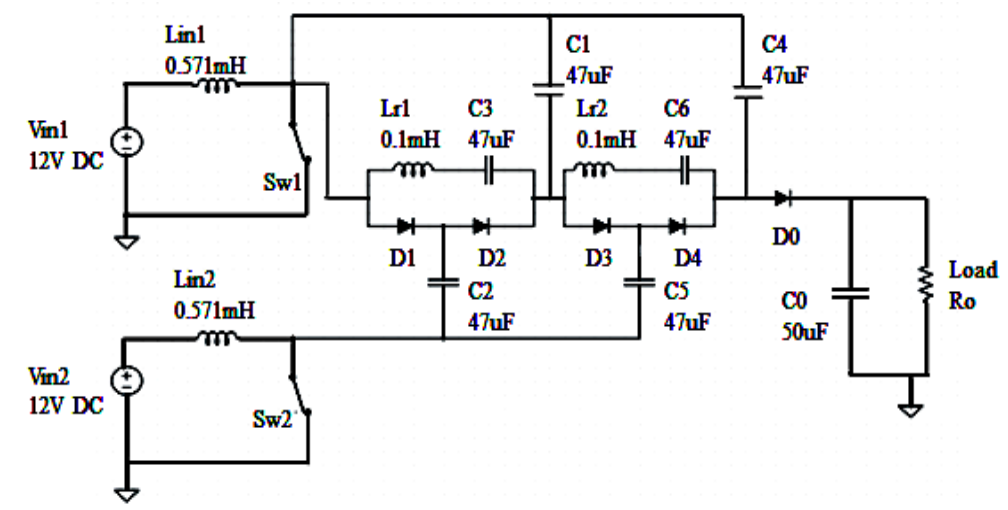

Figure 4. Modified two-input boost converter with voltage multiplier cell.

citors (C2, C5) and discharging the capacitors (C1, C4). If the number of VM stages is odd, then the output diode Do is reverse biased and the load is supplied by the output capacitor. However, if the number of VM stages is even, then the output diode is forward biased charging the output capacitor and supplying the load. In the particular case considered here, since there are four VM stages, the output diode is forward biased.

C. Third Operation Mode: In this mode switches S1 and S2 are turned ON and resonant inductor Lr and the output diode Do current reduce linearly to zero. Thus the reverse recovery current of the output diode is also minimized.

D. Fourth Operation Mode: In this mode S1 and S2 are turned OFF, when output diode is blocked, DM2 conducts and transfers the energy stored in the capacitor CM1 to CM2. When there is a balance of energy between the multiplier capacitors, the diode DM2 is blocked (t4) also with low di/dt. During the switch turn on the input inductor stores some energy as the classical boost.

\section{Simulation Results}

The simulation of the converters with \& without voltage multiplier cell is done by using the MATLAB/Simulink tool and the results are analyzed.

The output voltage and output current waveform of Proposed Two-Input Boost Converter without Voltage Multiplier Cell/Proposed Two-Input Voltage Multiplier Cell with Voltage Multiplier Cell/Proposed Two-Input Boost Converter with Voltage Multiplier Cell/Modified Two-Input Boost Converter with Voltage Multiplier Cell are given in Figures 5(a)-(d). The output voltage waveform of modified converter was well settled at 136.5 V. There exists less overshoots before settling the voltage waveform and the output voltage waveform is less from ripples. The voltage across the switches of Modified Two-Input Boost Converter with Voltage Multiplier Cell is given in Figure 5(e) which is very low when compared tom other topologies. The output voltage ripple is shown in Figure 5(f) which is about $4 \mathrm{~V}$ when compared to other topologies.

\section{Result Comparison}

The Table 1 shows the performances of different converter topologies and it shows that the best topology is modified two-input boost converter with VMC.

\section{Conclusion}

The principle of operation and analysis of different converters with modified DC-DC converter are presented in this paper. The high voltage gain with low duty cycle is achieved for the modified topology. The modified converter significantly minimizes the voltage stress in the two active diodes and switches with high voltage gain. This approach will lead to reduce switching and conduction losses and also to select MOSFET and diodes with lower voltage rating respectively. Furthermore, the topology explores the way to eliminate the usage of additional circuitry, complex control and also guide to uniform current sharing. From the analysis and comparison of results, the high step-up voltage gain with low duty cycle and reduced switch voltage stress modified converter is ap- 

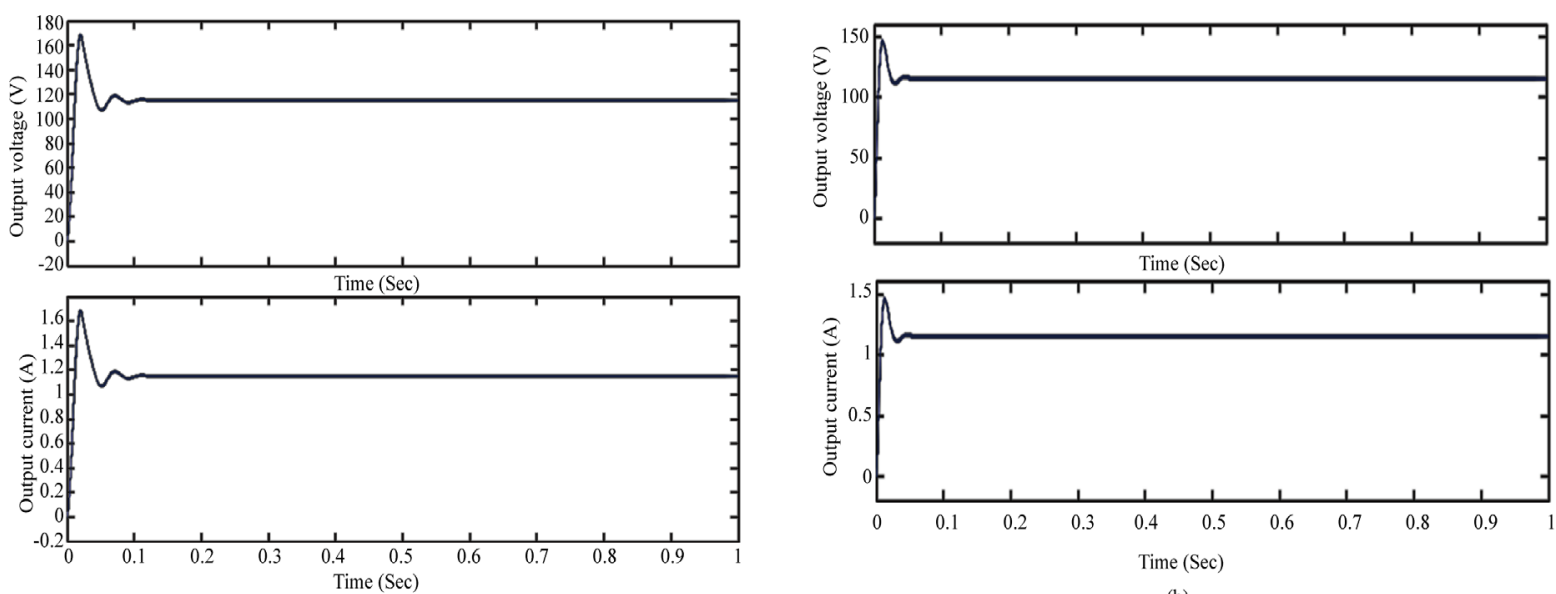

(a)

(b)
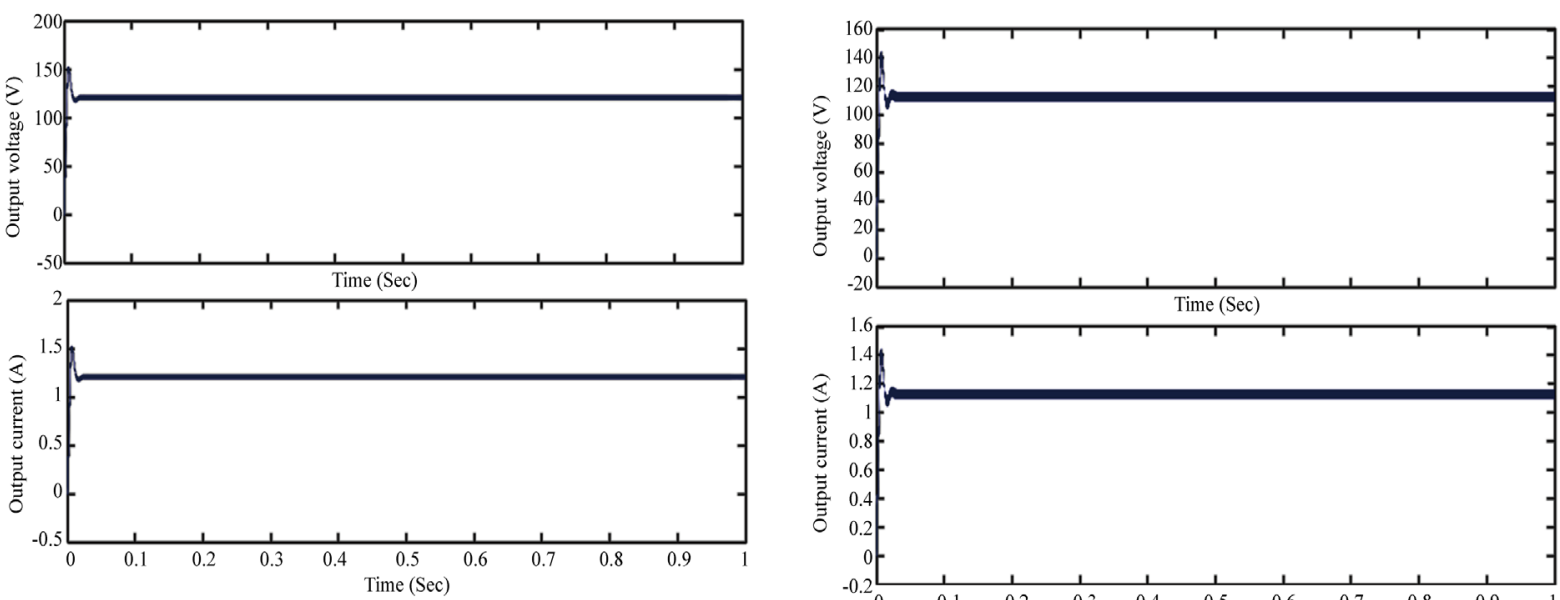

(c)

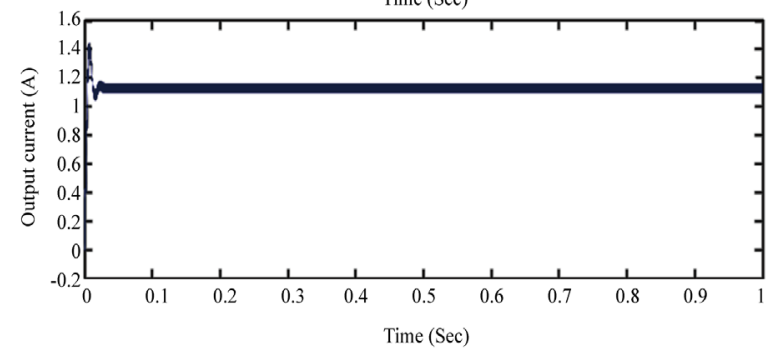

(d)
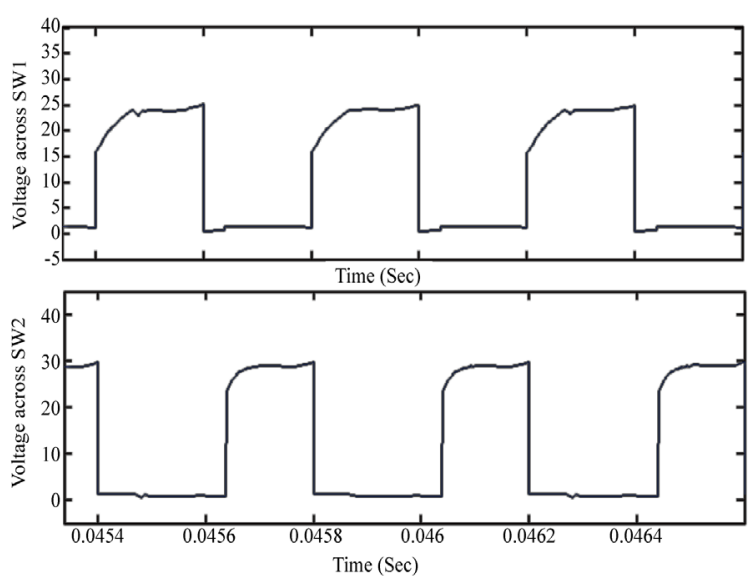

(e)

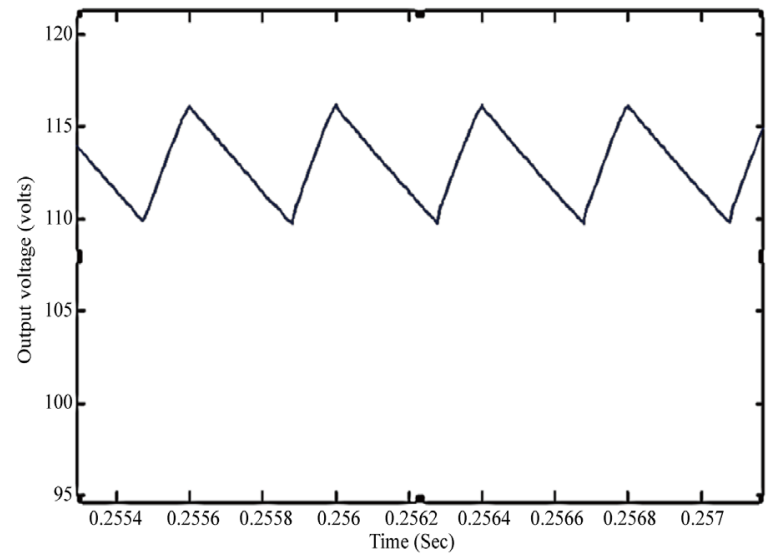

(f)

Figure 5. (a) Output voltage and output current waveform for proposed two-input boost converter without voltage multiplier cell; (b) Output voltage and output current waveform for proposed two-input voltage multiplier cell with voltage multiplier cell; (c) Output voltage and output current waveform for proposed two-input converter with and without voltage multiplier cell; (d) Output voltage and output current of modified two-input converter modified two-input boost converter with voltage multiplier cell; (e) Voltage across the switches of modified converter; (f) Output voltage ripple of modified converter. 
Table 1. Comparison of results.

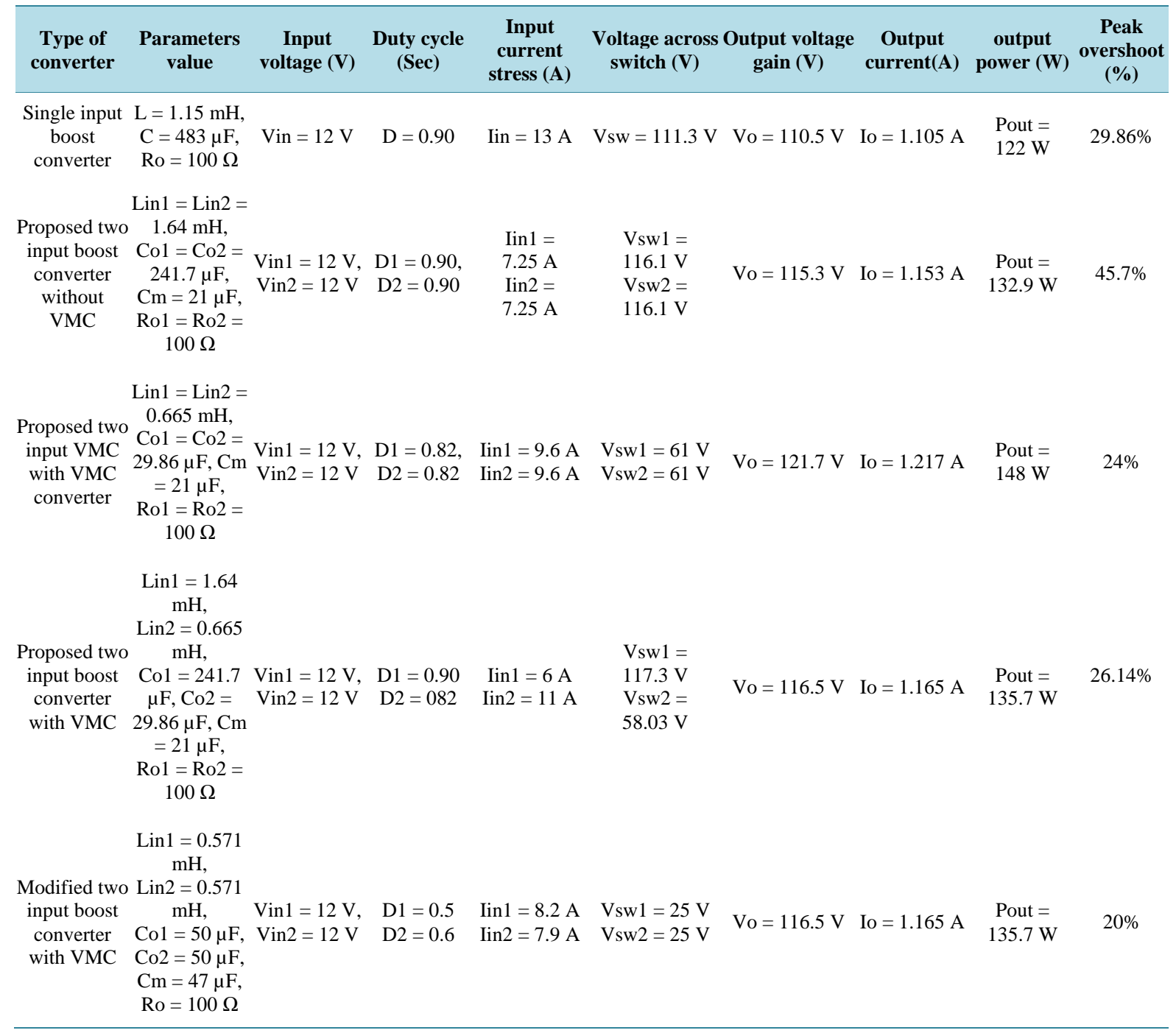

propriate one for multi-input source applications.

\section{References}

[1] Liand, W. and He, W. (2011) Review of Non-Isolated High Step-Up DC/DC Converters in Photovoltaic Grid-Connected Applications. IEEE Transaction on Industrial Electronics, 58, 1239-1250. http://dx.doi.org/10.1109/TIE.2010.2049715

[2] Zhu. L. (2006) A Novel Soft-Commutating Isolated Boost Fullbridge ZVS-PWM DC-DC Converter for Bidirectional High Power Applications. IEEE Transaction on Power Electronics, 21, 422-429. http://dx.doi.org/10.1109/TPEL.2005.869730

[3] Wai, R.J., Wang, W.H. and Lin, C.Y. (2008) High-Performance Stand-Alone Photo Voltaic Generation System. IEEE Transaction on Industrial Electronics, 55, 240-250. http://dx.doi.org/10.1109/TIE.2007.896049

[4] Wai, R.J. and Wang, W.H. (2008) Grid-Connected Photovoltaic Generation System. IEEE Transaction on Circuits Systems, 55, 953-964. http://dx.doi.org/10.1109/TCSI.2008.919744

[5] Yang, L.S., Liang, T.J. and Chen, J.F. (2009) Transformer Less DC-DC Converters with High Step-Up Voltage Gain. IEEE Transaction on Industrial Electronics, 56, 3144-3152. http://dx.doi.org/10.1109/TIE.2009.2022512

[6] Wildrick, C.M., Lee, F.C., Cho, B.H. and Choi, B. (1995) A Method of Defining the Load Impedance Specification for a Stable Distributed Power System. IEEE Transaction on Power Electronics, 5, 280-285. 
http://dx.doi.org/10.1109/63.387992

[7] Wai, R.J. and Duan, R.Y. (2005) High Step-Up Converter with Coupled Inductor. IEEE Transaction on Power Electronic, 9, 1025-1035. http://dx.doi.org/10.1109/TPEL.2005.854023

[8] Feng, X.G., Liu, J.J. and Lee, F.C. (2002) Impedance Specifications for Stable DC Distributed Power Systems. IEEE Transaction on Power Electronics, 3, 157-162. http://dx.doi.org/10.1109/63.988825

[9] Erickson, R.W. and Maksimovic, D. (2001) Fundamentals of Power Electronics. Kluwer Academic, Beilin.

[10] Mohan, N., Undeland, T.M. and Robbins, W.P. (1995) Power Electronics. John Wiley \& Sons, Hoboken.

[11] Freitas, N.A., Antun, F., Mineiro, E., Lima, A., Gadelha, A. and Gualter, F. (2012) DC-DC High Gain Converter Applied to Renewable Energy with New Proposed to MPPT Search. International Conference on Renewable Energies and Power Quality (ICREPQ’12), Santiago De Compostela, 28-30 March 2012.

[12] Huber, L. and Jovanovic, M.M. (2000) A Design Approach for Severe Power Supplies for Networking. Proceedings of Applied Power Electronics Conference, New Orleans, 6-10 February 2000, 1163-1169. 